\title{
Museums of martyrdom and the pedagogy of remembrance in the context of shaping students' attitudes and future competences
}

\author{
Marta Milewska
}

Dr Marta Milewska

Vistula University in Warsaw

OBBH IPN in Warsaw

Poland

e-mail: m.milewska@vistula.edu.pl

ORCID:0000-0003-3283-4037

Muzeológia a kultúrne dedičstvo, 2021, 9:4:21-39

DOI: $10.46284 / \mathrm{mkd} .2021 .9 .4 .2$

\begin{abstract}
Museums of martyrdom and the pedagogy of remembrance in the context of shaping students' attitudes and future competences

Museums of martyrdom operate on the sites of former Nazi concentration camps in Poland as memorials to the events of the Second World War. These institutions are part of the pedagogy of remembrance, which is an educational discipline connected with the theories of the German philosopher Theodor W. Adorno. The pedagogy of remembrance assumes that as part of the didactic process, it is important not only to learn about atrocities, but above all to analyse their causes. The discussion and debate surrounding the pedagogy of remembrance have allowed this article to identity the correlation between its assumptions and the shaping of students' attitudes as well as the development of skills included in the key competences. These competences are also referred to in a broader sense as competences of the future, as they are necessary for an individual to function properly in society. The aim of this article is therefore to clarify whether and how museums of martyrdom and the pedagogy of remembrance can foster the development of the skills defined as competences of the future. This article also attempts to indicate the museum activities and didactic methods that can be used by educators at places of remembrance in order to shape attitudes and develop key competencies.
\end{abstract}

Keywords: museum, museum of martyrdom, pedagogy of remembrance, key competences, competences of the future

In recent years, technological developments have changed the role of the museum. Museums that limit themselves to traditional exhibits have come to be seen as unresponsive to public expectations. ${ }^{1}$ Those that more closely resembled places of mass communication rather than "elite salons" have become more popular. ${ }^{2}$ Museums, including museums of martyrdom, have thus began to function not only as guides to the past, but also as animators of social life. ${ }^{3}$ According to Krzysztof Pomian, this is because visitors come to museums with specific expectations shaped by the media, and thus are not satisfied by the "classical" ways of displaying objects. Today's visitors want something more-presentations and animations that stimulate not only their eyes, ears, and nose, but also their minds, feelings, and emotions. "They

${ }^{1}$ CASEY, Edward. The Face of Place. A Philosophical History. Berkeley: University of California Press, 1997, p. 13; MALPAS, Jodi Ellen. Place and Experience: A Philosophical Topography. Cambridge: Cambridge University Press, 1999, p. 35.

${ }^{2}$ MAJEWSKI, Piotr. Muzeum jako instytucja komunikacji społecznej, Narodowy Instytut Muzealnictwa i Ochrony Zabytków, accessed 14 December 2020, http: https://docplayer.pl/7438611-Muzeum-jako-instytucja-komunikacji -spolecznej-1.html.

${ }^{3}$ CZERNER, Anna and NIEROBA, Elżbieta. Na styku bistorii i codz̨ienności. Spoteczność lokalna wobec miejsc pamięci. Opole: Centralne Muzeum Jeńców Wojennych, 2017, p. 306. 
want the exhibits to also be a show". ${ }^{4}$ In response to these expectations, museums are trying to implement new media techniques. ${ }^{5}$ According to Dorota Folga-Januszewska, modern models for museum operations should, however, take into account the use of appropriate didactic methods to foster socially desirable attitudes and skills. ${ }^{6}$ In the contemporary educational model, particular attention is paid to shaping the skills necessary for an individual to function in society, that is, key competences, and in a broader sense, competences of the future. ${ }^{7}$ Certain questions then arise: Can the educational activities of museums of martyrdom in the social space foster the development of the skills defined as competences of the future? Will a visit to a museum of martyrdom produce only knowledge, or will it produce skills and attitudes that are important from a competence perspective?

As defined in the Dictionary of the Contemporary Polish Language, the word kompetencja (competence) means "an appropriate range of knowledge and skills, professionalism, ability, and practical knowledge". ${ }^{8}$ General competences, on the other hand, are the knowledge, skills, and attitudes acquired through education in primary and secondary schools. ${ }^{9}$ These competences "are primarily related to the intellectual development of students with a broad introduction to the world of humanities and social sciences".${ }^{10}$ However, the development of science and technology is generating civilisational progress. The future will bring changes that will require people to have specific knowledge and skills in order to be able to respond effectively to new realities - that is, they must have the right competences. With key competences in mind, the educational process has begun to be designed to make students aware of the need to be constantly learning and to respond appropriately to dynamic situations. ${ }^{11}$ Key competences represent the chance for a smooth transition from the competences needed today to the as yet undefined competences of the future. In addition to key competences, the following may also be defined as the social competences of the future: communication, conflict resolution, negotiation, group work, organisation, creativity, mental flexibility, and learning to learn. ${ }^{12} \mathrm{We}$ are living in a changing reality; various aspects of our lives are changing, including educational curricula, and with them the scope and role of education in shaping the competences of the future. In the modern world, we observe the demand for a form of education which,

\footnotetext{
${ }^{4}$ POMIAN, Krzysztof. Muzeum: kryteria sukcesu. In: Muzealnictwo, 50, 2009, pp. 57-64.

${ }^{5}$ BANACH, Krzysztof. Muzeum martyrologiczne jako muzeum konstruktywistyczne. In: KRANZ, Tomasz (ed). Muzea w poobozonych miejscach pamięci. To šsamość, znaczenia, funkcje. Lublin: Państwowe Muzeum na Majdanku, 2017, p. 77.

${ }^{6}$ FOLGA-JANUSZEWSKA, Dorota. Muzeum: definicja i pojęcie. Czym jest muzeum dzisiaj? In: Mureologia, 49, 2008, pp. 200-204.

${ }^{7}$ Compare: HEIN, George. Learning in the Museum. London: Routledge, 1998; ZACHARIAS, Wolfgang. Zeitphänomen Musealisierung. Das Verschwinden der Gegenwart und die Konstruktion der Errinerung. Essen: Klartext, 1990; HARTMUT, John and DAUSCHEK, Anja. (eds). Museen neu denken. Perspektiven der Kulturvermittlung und Zielgruppenarbeit. Bielefeld: Transcript Verlag, Landschaftsverband Rheinland, Rheinisches Archiv—und Museumsamt, 2008; YVONNE, Leonard (ed). Kindermuseen, Strategien und Methoden eines aktuellen Museumstyps. Bielefeld: Transcript Verlag, 2012.

${ }^{8}$ SIKORSKA-MICHALAK, Anna. WOJNIŁKO, Olga (eds). Stownik wspótczesnego jesyka polskiego. Warszawa: Wydawnictwo Wilga, 1996, p. 398.

${ }^{9}$ KWIATKOWSKI, Stanisław. Kompetencje pryyszłości. In: KWIATKOWSKI, Stanisław (ed). Kompetencje praysžłości. Warszawa: Fundacja Rozwoju Systemu Edukacji, 2018, p. 17.

${ }^{10}$ OKOŃ, Wincenty. Nony stownik, pedagogiczny. Warszawa: Wydawnictwo Akademickie Żak, 2001, p. 1041-2005.

${ }^{11}$ KWIATKOWSKI, Kompetencje pryyszztości...,p. 28.

${ }^{12}$ MAYER, Jack and SALOVEY, Peter. Czym jest inteligencja emocjonalna? In: SALOVEY, Peter and SLUYTER Dawid (eds). Rožwój emocjonalny a inteligencja emocjonalna. Problemy edukacyjne. Poznań: Dom Wydawniczy Rebis, 1999, pp. 344-345.
} 
while transmitting the values of one's own nation and its culture, at the same time fosters the development of key competences. It is therefore worth considering whether museums of martyrdom in Poland and the pedagogy of remembrance may be part of this educational trend.

Museums of martyrdom operate on the grounds of former Nazi camps in Poland as memorials to the events of the Second World War. In Poland in the 1980s and 1990s, these museums experienced a sharp decline in interest in their activities, which was related to the ongoing political transformation of the period. ${ }^{13}$ For several years now, these museums have been experiencing a kind of renaissance, as evidenced by an increasing number of visitors. The largest museum of martyrdom in Poland, the Auschwitz-Birkenau Memorial and Museum, was visited by around 500,000 people a year in the 1990s. In recent years, that figure has risen to 1.5 million visitors. The State Museum at Majdanek observed a similar increase. In the 1990s the site was visited by around 100,000 people a year. In 2015-2016, this number increased to 150,000 visitors per year. ${ }^{14}$ These figures indicate increased interest in places of remembrance as well as the need for museum educators to constantly create new didactic methods in response to the changing needs of society and to develop key competencies. ${ }^{15}$

In the 1980s, there was a clear shift in European museum studies away from intuitive operations and towards a practice based on socio-pedagogical theories. ${ }^{16}$ The combination of the aforementioned theories with elements of psychology, cognitive science, and knowledge theory has resulted in a variety of educational strategies at places of remembrance. These strategies, according to Krzysztof Banach, "are not [...] usually without influence on the exhibition activities of the institutions where they are implemented". ${ }^{17}$ Taking into account educational needs, museums of martyrdom have thus expanded their activities by making their collections more accessible and interactive. ${ }^{18}$ Most such institutions in Poland, including the Auschwitz-Birkenau Memorial and Museum, the Stuthoff Museum, the State Museum at Majdanek, the Gross-Rosen Museum in Rogoźnica, and the Central Museum of Prisoners of War in Lambinowice-Opole have adapted their exhibitions to visitors' needs and expectations. Exhibitions are still their primary activity, but they now also take into account didactic methods and the need to develop future competences. Keeping in mind the three pillars of historical education-knowledge, skills, and attitudes-these museums of martyrdom strive to make places of remembrance into institutions which not only transmit knowledge, but also help shape attitudes and skills in accordance with didactic concepts of historical education about the Second World War.

Pierre Nora was the first to analyse the collective memory of a given community through the description of the topography of recognisable memorial sites. ${ }^{19}$ In his case, the community was the French nation. In Germany, the concept of memorial sites was developed by Etienne François and Hagen Schulze, who, unlike Pierre Nora, did not use the nation as the basis of reference, but invited historians, ethnologists, sociologists, lawyers, etc. to cooperate. ${ }^{20}$ These $^{2}$

13 FOUCAULT, Michel. Discipline and Punish. The Birth of the Prison. New York: Random House, 1975, p. 26; ADAMSKA, Jolanta. Pamięć i miejsca pamięci w Polsce po II wojnie światowej. In: Pržeszłość i Pamiéć, 1, 1998, p. 9.

${ }^{14}$ ADAMSKA, Pamię́ $i$ miejsca..., p. 9.

15 BANACH, Muzeum martyrologiczne jako..., p. 73.

${ }^{16}$ HEIN, Learning in the Museum ..., p. 34.

17 BANACH, Muzeum martyrologiczne jako..., p. 74.

${ }^{18}$ CZERNER, Nieroba, Na styku historii i codzienności..., p. 306.

${ }^{19}$ NORA, Pierre. Les lieux de mémoire, Paris: Gallimard, 1984-1992, pp. 1-7.

${ }^{20}$ FRANCOIS, Etienne and SCHULZE Hagen (eds). Deutsche Erinnerungsorte, vol. 1-3. München: Verlag C.H. Beck, 2001-2003. 
activities resulted in the analysis of memorial sites in various countries. ${ }^{21}$ The studies created in this way currently support the pedagogy of remembrance, which, on the one hand, sustains the memory of the victims of Nazi crimes, and on the other, shapes social attitudes and behaviour desired in democracy. ${ }^{22}$

The origin of the pedagogy of remembrance as an educational trend is linked to the theories of the German philosopher Theodor W. Adorno, who in his essay Erziehungnach Auschwitz. (Education after Auschwitz) emphasised that the mere remembrance of the atrocities committed by the Nazis during the Second World War does not guarantee that these tragic events will not be repeated in the future. Adorno's postulate "that Auschwitz should never happen again" became the starting point for the concept known as the pedagogy of remembrance. Following his theory, it was not only sharing knowledge about the atrocities, but above all analysing their causes that was essential to the didactic process. Thus, a characteristic element of Adorno's concept of "education after Auschwitz" was to make the next generation aware of the social and psychological mechanisms that led to the crimes. According to Adorno, analysing the causes of the crimes was aimed at developing desirable attitudes and behaviours, such as critical thinking, the ability to express one's own views, and the ability to negotiate and discuss, as well as the formation of civic attitudes. ${ }^{23}$ Despite the passage of time, these attitudes and skills have not lost their relevance, and are even part of the competences of the future.

The museum spaces at concentration camp sites are places of remembrance which contextualise the process of analytical reflection and give it an exemplified character, while the educational activities are features of concretised social prevention. ${ }^{24}$

The above considerations indicate a correlation between the assumptions of the pedagogy of remembrance and the development of the skills and competences that are key to the proper functioning of an individual in society.

The development of the concept of the pedagogy of remembrance was first observed in Germany. It was initially seen as part of a process of reckoning between German society and the legacy of Nazism. In the early 1970s, this concept formed the basis for the activities of the Action Reconciliation Service for Peace (AktionSühnezeichen) and was developed into a form of historical and political education. The Action Reconciliation Service for Peace is an organisation that arranges educational trips to the sites of former concentration camps in Poland. On the

\footnotetext{
${ }^{21}$ BANK, Jan and MATHIJSEN, Marita. Plaatsen van herinnering. Nederland in de negentiende eeuw. Amsterdam: Bert Bakker, 2011; BRIX, Emil, BRUCKMüLLER Ernst, and STEKL, Hannes (eds). Memoria Austriae, vol. 1-3. WienMünchen: Verlag für Geschichte und Politik 2004-2005; KMIEC, Sonja, MAJERUS, Bonoit, MARGUE, Michel, and PEPORTE, Pit. Lieux de mémoire au Luxembourg. Usages du passé et construction nationale. Erinnerungsorte in Luxemburg. Umgang mit der Vergangenheit und Konstruktion der Nation. Luxembourg: Éditions Saint-Paul 2007; KRIES, Georg. Schweizer Erinnerungsorte. Aus dem Speicher der Swissness. Zürich: Verlag Neue Zürcher Zeitung, 2010; PRAK, Maarten. Plaatsen van herinnering. Nederland in de zeventiende en achttiende eeuw. Amsterdam: Bert Bakker, 2006.

${ }^{22}$ SCHEURICH, Imke. NS-Gedenkstätten als Orte kritischer historiach-politischer Bildung. In: THIMM, Barbara, KößLER, Gotfriet. and ULRICH, Susanne (eds). Verunsichernde Orte. Selbstverständnis und Weiterbildung in der Gedenkstättenpädagogik. Frankfurt am Main: Brandes und Apsel, 2010, pp. 38-44; RATHENOW, Hanns-Fred. Gedankstättenpädagogik. In: RICHTER, Dagmar and WEIßENO, Georg (eds). Lexikon der politischen Bildung. Bd. 3 (Didaktik Und Schule). Schwalbad: Wochenschau Verlag, 1999, pp. 79-82; KROH, Jens. Transnatiionale Erinnerung. Der Holocaust im Fokus geschichtspolitischer Iniciativen. Frankfurt-New York: Amazon.de: Bücher, 2006.

${ }^{23}$ ADORNO, Theodor W. Erziehung zur Mündigkeit. Frankfurt: Suhrkamp; 1. Auflage, 1970, p. 92.

${ }^{24}$ BANACH, Muzeum martyrologiczne jako..., p. 76.
} 
one hand, these trips are intended as an expression of solidarity with the victims of the Second World War, while on the other hand, they are an opportunity to learn about Nazism at the scenes of its crimes. ${ }^{25}$ The memorial education (Gedenkstättenpädagogik) initiated by German researchers was also aimed at reflecting on the phenomenon of remembrance itself and its usefulness in didactic education. ${ }^{26}$

According to the German theorists of the pedagogy of remembrance Norbert H. Weber and Hanns F. Rathenow, places of remembrance are places where we encounter "iron witnesses", that is, objects that transmit knowledge and help shape our attitudes. ${ }^{27}$ Thus, in the German understanding, the pedagogy of remembrance became a form of historical and social education aimed at promoting the memory of the victims of Nazi crimes and shaping socially acceptable attitudes and behaviours. ${ }^{28}$ According to Rathenow, when conducted within the framework of the pedagogy of remembrance, the educational process should combine active action with affective and pragmatic elements. ${ }^{29}$

In the 1990s, German museums played an important role in the development of the pedagogy of remembrance and may be considered as catalysing a culture of remembrance.

In general, in the German understanding, the pedagogy of remembrance promotes an active, open, and multifaceted confrontation of the past and combines historical reflection with the creation of attitudes and behaviours desirable in a democracy,

wrote Tomasz Kranz. ${ }^{30}$ The pedagogy of remembrance is a concept that emphasises the didactic and educational importance of knowledge of Nazi crimes, and particularly knowledge acquired at museums at the sites of former Nazi concentration camps. ${ }^{31}$ Educational activities carried out within the framework of the pedagogy of remembrance should be oriented towards learning about the history of the given place - a Nazi concentration camp-and towards stimulating thought processes that foster critical thinking and broaden historical awareness. ${ }^{32}$ The above considerations on the pedagogy of remembrance indicate that there is great potential for its use in the process of forming key competences.

\footnotetext{
${ }^{25}$ SKRIVER, Ansgar. Aktion Suebnezeichen. Bruecken uber Blut und Asche. Stuttgart: Walter de Gruyter, 1962, pp. 131135; KRANZ, Tomasz. Pedagogika pamięci. In: Nigdy wiecej, 18, 2010.

${ }^{26}$ See: BRINKMANN, Annette (ed). Learning from History. The Nazi Era and the Holocaust in German Education. Bonn: American Association of Teachers of German, 2000; EHMANN, Annegret (ed). Praxis der Gedenkstättenpädagogik. Erfahrungen und Perspektiven. Opladen: Leske und Budrich, 1995; KAHLS Heike. Erinnern lernen? Pädagogische Arbeit in Gedenkstätten, Münster: Agenda Päda-gogik, 1996; KRANZ, Tomasz. Einleitung. In: KRANZ. Tomasz (ed), ZurPädagogike der Erinnerung. Bedingungen, Ziele und Methodenhistorischer Bildung in Gedenkstätten. Lublin: Państwowe Muzeumna Majdanku, 2015, p. 8.

${ }^{27}$ WEBNER. Norbert and RATHENOW, Hanss-Fred. Pedagogika miejsc pamięci—próba bilansu. Translated by SZYMAŃSKI, Mirosław and LEWANDOWSKA, Izabela. In: Kwartalnik Pedagogiczny, 2, 1996, p. 24.

${ }^{28}$ SCHEURICH Imke. NS-GedenkstättenalsOrtekritischerhistorisch-politischerBildung, In: THIMM, Barbara, KÖßLER, Gottfried, and ULRICH, Susanne (eds). VerunsicherndeOrte, Selbstverständnis und Weiterbildung in der Gedenkstättenpädagogik. Frankfurt am Main: Brandes + Apsel Verlag Gm, 2010, pp. 38-44.

${ }^{29}$ RATHENOW, Hanns-Fred. Gedenkstättenpädagogik. In: RICHTER, Dagmar and WEIßENO, Georg (eds), Lexikon der politischenBildung, vol. 3 (Didaktik, und Schule). Schwalbad: WochenSchau Verlag, 1999, pp. 79-82.

${ }^{30}$ KRANZ, Tomasz. Pedagogika miejsc pamięci. In: Obyczaje, 16, 2004, pp. 5-8.

${ }^{31}$ KRANZ Tomasz. Pedagogika miejsc pamięci. In: PILCH, Tadeusz (ed), Encyklopedia pedagogiczna XXI wieku, vol.

4. Warszawa: Wydawnictwo Akademickie Żak, 2005, pp. 1701-1772.

${ }^{32}$ KRANZ, Tadeusz. Uwagi na temat rozwoju działalności pedagogicznej muzeów upamiętnienia w Polsce i Niemczech. In: Zesayty Majdanka, 22, 2003, pp. 4014-4015.
} 
The principles of the pedagogy of remembrance were gradually developed in Poland from the 1990s onwards by the museums of martyrdom established at the sites of the former concentration camps in Auschwitz, Stutthoff, and Majdanek. In Communist Poland, these museums conducted mainly awareness and propaganda activities. It was not until the late 1990s that the educational activities of Polish museums of martyrdom began to change. They began to focus not only on imparting historical knowledge, but also on stimulating thought processes. ${ }^{33}$ The development of the pedagogy of remembrance in Poland was a process that required a change in museums' self-awareness as institutions of historical and social education and required them to define the scope of their activities as places of remembrance and to create appropriate methodological and material conditions. To use the pedagogy of remembrance in the teaching process, museums also had to cooperate with schools in the areas of methodology and didactics. ${ }^{34}$

Although the pedagogy of remembrance has both a theoretical basis and a developed methodology, it is still difficult to find a definition that fully reflects its essence, aims, content, and educational forms. ${ }^{35}$ This is because the pedagogy of remembrance is based on the assumption that in the educational process, the perception of authentic historical places should be kept in mind, as should reflection on the memory of the past. The scenes of atrocities evoke specific impressions and feelings that can lead us to experience and learn about the past. The memory of the past is "a constitutive element of individual and collective identities and at the same time a matrix that shapes the way we perceive and understand the world". ${ }^{36}$ Cultivating the memory of historical events is seen today as an important element in the life of the individual and a nation. According to the French researcher of memory and history, Pierre Nora, "memory [...] is life: its bearers are always groups of the living". ${ }^{37}$ According to A. D. Smith, cultivating memory and the past is essential to the survival of society. ${ }^{38}$ Each individual and collective memory - social, national, and cultural - is the basis of human development. ${ }^{39}$ This view was also shared by M. Foucault, who recognised that memory is an important cultural and political resource. $^{40}$

Social memory is about generations of children, grandchildren, great-grandchildren and even further social inheritors having a sense of some continuity with their predecessors' generations, and thus a sense of continuity of fortune, a sense of identity and responsibility for the past and the future. ${ }^{41}$

\footnotetext{
${ }^{33}$ KRANZ, Pedagogika miejsc pamieci..., p. 6.

${ }^{34}$ Ibid., p. 6.

${ }^{35}$ KRANZ, Tomasz. Pedagogika pamięci jako forma edukacji muzealnej. In: KRANZ, Tomasz (ed). Wiayty edukacyjne w Państwonym Muzeum na Majdanku. Poradnik dla naucaycieli. Lublin: Muzeum Państwowe na Majdanku, 2012, pp. 111-115.

${ }^{36}$ KRANZ, Pedagogika miejsc pamięci..., p. 6.

${ }^{37}$ Compare: NORA, Pierre. Rethinking France. Les Lieux de memoire, Vol. 2: Space. Chicago: University of Chicago Press, 2006; NORA, Pierre. Between Memory and History. Les Lieux de mémoire. In: Representation, $26,1989$.

${ }^{38}$ SMITH, Anthony. Myths and Memories of the Nation. Oxford-New York: Oxford University Press, 2000 , p. 34.

${ }^{39}$ Compare: NIETZSCHE, Friedrich. On the Advantage and Disadvantage of History for Life. Indianapolis: Hackett, 1980; RICOEUR, Paul. Memory, History, Forgetting. Chicago: University of Chicago Press, 2004.

${ }^{40}$ FOUCAULT, Michel. Discipline and Punish: The Birth of the Prison. New York: Random House, 1975, p. 25.

${ }^{41}$ GOLKA, Marian. Pamię́ spoteczna i jej implanty. Warszawa: Scholar, 2008, p. 8.
} 
Past events, as Alan R. H. Baker rightly pointed out, can evoke an overriding sense of unity. ${ }^{42}$ The above considerations lead to the conclusion that the past influences the present. This fact has become one of the postulates of the pedagogy of remembrance, namely "to learn from history". ${ }^{43}$ It is worth noting that the pedagogy of remembrance has many points of contact with regional and intercultural education and thus is becoming part of European education. In turn, intercultural communication promotes dialogue between peoples, combats stereotypes, and raises awareness of diversity. ${ }^{44}$

Today, the pedagogy of remembrance is seen not only as a form of critical historical selfawareness, but also as an element of the educational process which shapes active attitudes towards threats to democracy and human rights violations. The general aim of contemporary pedagogy of remembrance is to help visitors learn about the history of a place of martyrdom. On the other hand, its specific objectives are about activating the cognitive process, which is important for our internal development. Museums of martyrdom and their memorials are thus intended to "facilitate orientation in the world and stimulate social activity". ${ }^{45}$ An analysis of the aims of the pedagogy of remembrance may conclude that it fosters the development of skills which are also important from the perspective of key competences.

The educational activities conducted at places of remembrance not only foster the development of cognitive attitudes, but also support the shaping of the key competences developed when learning about history. The postulates of the pedagogy of remembrance are compatible with the general aims of education on the Second World War. This was also pointed out by Tomasz Kranz, who wrote,

the basic didactic postulate from the perspective of the Second World War is to indicate the necessity of shaping a sense of responsibility and creating an attitude of tolerance and sensitivity to the feelings and values of other people. Responsibility and empathy are therefore the primary categories of civic education referring to historical heritage. ${ }^{46}$

In the light of the definition included in Wincenty Okoń's Stównik pedagogiczny (Dictionary of Pedagogy), civic education is

raising awareness of the functional mechanisms of the modern state, aimed at shaping social, civic, and patriotic feelings and attitudes, as well as preparation for practical activities related to functioning as citizens of the state. ${ }^{47}$

\footnotetext{
${ }^{42}$ BAKER, Alan R. H. Geography and History: Bridging the Divide. Cambridge: Cambridge University Press, 2003 , p. 135; FAULKNER, William. Requiem for a Nun. New York: Random House, 1951, p. 73; AUGE, Marc. Non-Places: Introduction to an Anthropology of Supermodernity. New York-London: Verso, 1995, p. 34.

${ }^{43}$ KRANZ, Tomasz, Pedagogika pamięci jako forma edukacji..., p. 11.

${ }^{44}$ Compare: NEIRICH, Uwe. Erinnern heißt wachsam bleiben. Pädagogische Arbeit in und mit NS-gedenkstaätten. Mülheim: Verlag an der Ruhr, 2000; KLIMOWICZ, Anna.(ed). Edukacja miedzylkulturowa. Poradnik dla nauczyciela. Warszawa: Ośrodek Rozwoju Edukacji, 2004.

${ }^{45}$ WEBER, Norbert H. and RATHENOW, Hanns-Fred. Education at the memorials: an assessment. In: Kwartalnike Pedgogiczny, Wydział Pedagogiczny Uniwersytetu Warszawskiego, 2, 1996, pp. 376-379; KRANZ, Pedagogika miejsc pamięci..., p. 7.

${ }^{46}$ KRANZ, Tomasz. Edukacja historyczna w miejscach pamieci. Zarys problematyki. Lublin: Stowarzyszenie „Dialog i Współpraca", 2009, p. 19.

${ }^{47}$ OKON, Wincenty. Stownik pedagogiczny..Warszawa: Wydawnictwo Naukowe PWN, 1981, p. 349.
} 
M. Milewska: Museums of martyrdom and the pedagogy of remembrance in the context...

Krzysztof Banach, on the other hand, stated that

as a strategy of informal historical education about the Second World War, the pedagogy of remembrance may be classified as a progressive trend in education. ${ }^{48}$

According to WiesławWysok, the pedagogy of remembrance

links remembrance of the victims of the Nazi dictatorship with the shaping of the behaviours and values valued in a democracy and postulates that the learning process initiated at places of remembrance is oriented towards visitors' activeness and occurs on the intellectual, practical, affective, and reflective levels. ${ }^{49}$

Among the important features of the pedagogy of remembrance is the shift from focusing on teaching to learning. Learning to learn is a key competence. Independent learning therefore plays an important role in developing the competences of the future. This competence can be defined as the process by which students acquire specific knowledge, skills, and habits through direct and indirect learning about reality. According to Wiesław Wysok,

One of the necessary conditions [for self-education] is the individualisation of the learning process, understood as personally "living" and "experiencing" history, building new ways to approach the past, and forming one's own opinion about it. ${ }^{50}$

Museums of martyrdom are not only places of remembrance but also places of selfeducation; through their authenticity, they allow people to "live" and "experience" history.

Learning about the past through experience, that is, experiencing the authenticity of a place of remembrance, refers to the theory of American philosopher and educator John Dewey, who described a combination of cognition and action ("learning by doing"). ${ }^{51}$ The Dewey concept, upon which the pedagogy of remembrance draws, promotes teamwork and the acquisition of specific historical competences. Thus, the pedagogy of remembrance fosters the development of competences which are important for an individual to function in adult life, as it combines social and historical values. The emphasis on experience and experiential learning in the educational process is also characteristic of the pedagogy of remembrance. Tomasz Kranz has rightly pointed out that

of key importance is [...] the development of problem-oriented thinking and the skills desired in classroom education, which in turn shape historical culture and the preferred cognitive attitudes, and thus contribute to equipping learners with specific competences and skills and support the development of teamwork skills as well as the acquisition of

\footnotetext{
${ }^{48}$ BANACH, Muzeum martyrologiczne jako..., p. 78.

${ }^{49}$ WYSOK, Wiesław. Edukacja w muzeach upamiętnienia in situ-postulaty, możliwości i granice oddziaływania dydaktycznego. In: WYSOK, Wiesław and STEPNIAK, Andrzej (eds). Edukacja muzealna w Polsce. Aspek.ty, konteksty, ijęcia. Lublin: Muzeum Państwowe na Majdanku, 2013, p. 40.

${ }^{50}$ WYSOK, Wiesław. Wokół problematyki uwarunkowań i efektów edukacji w muzeach upamiętnienia. In: Zeszyty Majdanka, 26, 2014, pp. 3213-3222.

${ }^{51}$ Compare: DEWEY, John. Experience and Education. New York: Simon \& Schuster, 1997.-
} 
specific historical habits and competences. ${ }^{52}$

The pedagogy of remembrance creates the opportunity for direct contact with authentic documents and monuments at the museums on the sites of former Nazi concentration camps. One element of the pedagogy of remembrance is to conduct the educational process so as to leave space for students to reflect on the past on the one hand, and to encourage them to reflect on their own views and attitudes on the other. According to Tomasz Kranz,

In this view, the pedagogy of remembrance is an attempt to activate a moral and social dimension of the historical memory of totalitarian crimes and, at the same time, to stimulate future-oriented action in a spirit of emancipation and empathy. ${ }^{53}$

In the Official Journal of the European Union C189 of 4 June 2018, the Council Recommendation of 22 May 2018 on key competences for lifelong learning reads:

everyone has the right to quality and inclusive education, training and lifelong learning in order to maintain and acquire skills that allow full participation in society and successful transitions in the labour market. ${ }^{54}$

In this regard, the following competences were identified:

1) literacy competence;

2) multilingual competence;

3) mathematical competence and competence in science, technology, and engineering;

4) digital competence;

5) personal, social, and learning to learn competence;

6) citizenship competence;

7) entrepreneurship competence;

8) cultural awareness and expression competence..$^{55}$

It follows from the above that the key competences identified by the European Council include competences which can be developed at places of remembrance and through the educational activities of museums of martyrdom. All of the key competences listed above can be developed during the students' visits to museums of martyrdom. It is therefore worth pointing out a few examples. An educator's communication with students visiting the museum promotes the development of the literacy competence. Museums of martyrdom are located at the sites of Nazi concentration camps from the Second World War. During the tour, students encounter German words which require explanation from the educator-this should be combined with the development of the multilingual competence. Information on the area itself and the geography of the place of remembrance can in turn be linked to the development of the science, technology, and engineering competence. Any multimedia devices that the students

\footnotetext{
${ }^{52}$ KRANZ, Pedagogika pamięci..., pp. 171-178.

${ }^{53}$ Ibid., p. 8.

${ }^{54}$ Council Recommendation of 22 May 2018 on key competences for lifelong learning. Official Journal of the European Union C 189, p. 7, accessed on 4 February 2021, https://eur-lex.europa.eu/legal content/EN/TXT/HTML/?uri=O$\mathrm{J}: \mathrm{C}: 2018: 189:$ FULL\&from $=\mathrm{EN}$.

${ }^{55}$ Council Recommendations of 22 May 2018 on key competences..., pp.71-73.
} 
encounter during their visit to the museum may help develop the digital competence. A visit to the place of remembrance and its impact on students' emotions combined with an experiential education on the tragedies of the Second World War and the creation of didactic situations enabling independent education should be understood as developing the personal, social, and learning to learn competences. Educational activities at places of remembrance also foster the development of citizenship competences by highlighting the consequences of the failure to respect human rights. The image of prisoners' life in the camp and the need to adapt to the reality of the camp and develop the ability to cope with the conditions of the camp can be used in the analysis of skills included in entrepreneurial competences. The museum exhibition, on the other hand, fosters the development of the cultural awareness and expression competence.

Based on the considerations above, we may conclude that museums of martyrdom and the pedagogy of remembrance foster the development of particular key competences, althoughit should be clearly noted-to an unequal extent. Among the key competences, we may identify those to which the educational activities of museums of martyrdom may offer significant support. The key competences that can be developed at places of remembrance include literacy competence, personal, social, and learning to learn competence, and citizenship competence. It is citizenship competence that museums of martyrdom and the pedagogy of remembrance foster particularly strongly. This competence is defined as the ability to act and participate fully in civic and social life based on an understanding of social, economic, legal, and political concepts and structures, as well as global events and sustainable development. ${ }^{56}$ As a competence for the future, active citizenship means not only being a member of a political party, being active in non-governmental organisations, and participating in decision-making processes, but also cultivating democratic values such as human rights, multiculturalism, tolerance, etc. ${ }^{57}$

The ability to acquire axiological, social, and civic competences plays an important role in the educational process; according to the idea of lifelong learning, these competences should be constantly developed and defined. According to Krystyna Chałas, these competences are essential in preparing students to be effective in the future. ${ }^{58}$ Historical and civic education is responsible for their development. These competences include developing students' social and civic awareness, developing critical thinking, shaping attitudes, and instilling values. The role of modern education is not only to share knowledge, but also to improve practical skills and shape socially acceptable attitudes, such as tolerance, patriotism, and respect for other cultures and traditions. Museums of martyrdom are therefore good places to develop the skills and attitudes mentioned above.

We live in a dynamically changing reality and an uncertain future, and therefore shaping the citizenship competences that are included among the key competences should be afforded an appropriate place in the educational process. Thus, fostering students' interest in history based on the pedagogy of remembrance, cooperation between schools and museums of martyrdom,

\footnotetext{
${ }^{56}$ BORGENSZTAJN, Joanna, KARCZEWSKA-GZIK, Agnieszka, MILEWSKA, Marta, WITKOWSKA, Elżbieta, and MALINOWSKI, Michał. Wytyczne wraz z aneksem do tworzenia programów nauczania i scenariuszy zaję́. 2018, p.50, accessed 14 December 2020, https://www.ore.edu.pl/wpcontent/uploads/2018/08/wytyczne_wraz_z_aneksem_ do_tworzenia_programow_nauczania-1.pdf .

${ }^{57}$ NAPIONEK, Olga. Kompetencje społeczne i obywatelskie—czym są i w jaki sposób można je rozwijać dzięki projektom edukacyjnym? In: TOLWIŃSKA-KRÓLIKOWSKA, Elżbieta (ed), Dzieci obywatele. Warszawa: Fundacja Inicjatyw Oświatowych, 2013, p. 19.

${ }^{58}$ CHAŁAS, Krystyna. Przyszłość należy do świadomych i aktywnych obywateli. Jakie kompetencje są im niezbędne? Jak skutecznie je kształtować? (Perspektywa aksjologiczna). In: KWIATKOWSKI, Stanisław (ed), Kompetencje przyszłości. Warszawa: Fundacja Rozwoju Systemu Edukacji, 2018, p. 48.
} 
and experiential learning are essential elements in the process of developing key competences, that is, the knowledge, skills, and attitudes necessary for students to function properly in adult life. Education at places of remembrance creates a wide range of possibilities in terms of educational content, from historical knowledge, to moral value systems, to issues which shape the attitudes that are important for an individual to function in a society, such as a respect for human rights, tolerance, fighting discrimination, and responding to violence and aggression. ${ }^{59}$ Human rights, a sense of national identity, and openness to the achievements of other nations are shaped by reference to various historical events, including the difficult events of the Second World War, places of remembrance, and Nazi concentration and extermination camps. ${ }^{60}$

Museums of martyrdom not only provide knowledge, but also allow direct contact with the scene of the crime, enabling us to analyse the causes and effects of events, synthesise the information obtained, and draw the right conclusions. Education at memorials is based on their authenticity, which enables students to be emotionally involved, to form attitudes, and to develop interest in the past, and which teaches independent thinking and encourages active participation. A readiness to act, acceptance of differences, and respect for others' values and privacy are essential skills for the future. ${ }^{61}$ It is important that educators who conduct classes at museums of martyrdom use a variety of didactic methods, especially those methods that foster the development of key competences, and in particular the literacy, personal, social and learning to learn, citizenship, and cultural awareness and expression competences.

The need to develop key competences and the ability to use our knowledge in practice has meant that traditional teaching methods based mainly on the verbal delivery of information are now inadequate, for obvious reasons. ${ }^{62}$ A museum of martyrdom's activities should be based on methods which involve the pupils in the process of cognition and discovery, making them active participants in the learning process. In this respect, contemporary didactics point to activating methods which affect the effectiveness of the learning process and which motivate students to acquire knowledge independently and to develop interdisciplinary skills. ${ }^{63}$ When selecting didactic methods, places of remembrance should take into account the recommendations for methods that activate students' learning and creativity and the social dimension of education, as well as active and experiential education.

The methods that can be used by educators at museums of martyrdom and that have a positive impact on shaping attitudes and developing key competences include discussion, debate, negotiation, decision trees, projects, brainstorming, case analysis, and group work. ${ }^{64}$

\footnotetext{
${ }^{59}$ Compare: HAUG, Verena. Am „autentischen” Ort. Paradoxien der Gedenkstätten pedagogik. Berlin: Metropol Verlag, 2015; KRANZ, Pedagogika miejsc pamięci..., p. 7.

${ }^{60}$ MILEWSKA, Marta. Prawa człowieka w edukacji historycznej w gimnazjum. In: JASKIERNIA, Jerzy and SPRYSZAK, Kamil (eds). Ochrona praw çłowieka w Polsce. Aksjologia_instytucje—nowe wyzwania_praktyka, vol. IV. Toruń: Wydawnictwo Adam Marszałek, 2017, p. 35.

${ }^{61}$ MAZUR-RAFAL, Monika and SZAROTA, Magdalena. Edukacja na rzecz praw człowieka. Zarys metodologiczny. In: MILCZARSKI, Radosław, MAZUR-RAFAŁ, Monika, SZAROTA, Magdalena, LIPKA, Monika, and CZAJKA, Katarzyna (eds). Historia a prawa çłowieka. Podrecznik. Warszawa: Wydawnictwo Ośrodek Karta, 2013 , p. 34. ${ }^{62}$ TOTT, Samuel (ed). Teaching Holocaust Literature. Boston: Macmillan, 2001.

${ }^{63}$ PANIMASZ, Katarzyna and LEWANDOWSKI, Grzegorz (eds). Historia i społeczeństwo. Planowanie-realizacjaewaluacja. Warszawa: Ośrodek Rozwoju Edukacji, 2012, p. 7. The publication was created as part of the project "Implementation of the core curriculum of general education in kindergartens and schools".

${ }^{64}$ STAWOWY, Ewa. Edukacja o prawach człowieka. Strategia dla organizacji pozarządowych i placówek kulturalno -oświatowych. In: KOBA, Laura and WACŁAWCZYK, Wiesław (eds), Prawa człowieka. Wybrane zagadnienia i problemy. Warszawa: Oficyna a Wolters Kluwer Business, 2009, p. 574.
} 
In using activating methods, an educator works similarly to a teacher who only introduces the students to the issues of the day, who skilfully directs and motivates them, but who largely leaves the students to work on their own. ${ }^{65}$ The pedagogy of remembrance uses various forms of learning, including group work, discussion, storytelling, drama, etc. As they involve teamwork, these methods account for the social aspect of education. Being oriented towards practical action and experiential learning, they are therefore conducive to the formation of future competences. In the pedagogy of remembrance, the search for knowledge and understanding takes precedence over more traditional didactic methods, which also undoubtedly favours the development of key competences. However, developing the competences of the future at museums of martyrdom requires an appropriate organisational and time framework. A visit to a place of remembrance lasting several hours provides visitors with only general historical information, while projects, workshops, and seminars offer greater learning opportunities but also require greater organisational effort.

In addressing issues related to the martyrology of the place of remembrance, the project method is the gold standard. ${ }^{66}$ A project is a planned activity based on a division of labour whose aim is to produce a specific product, for example, a multimedia presentation, exhibition, film report, etc. Projects may deal with general issues related to the culture of remembrance or may be strictly related to a particular museum of martyrdom; they may be integrated in the curricula or directly related to a place of remembrance. The diversity of the issues related to museums of martyrdom and the wide range of available themes mean that such projects should be given the appropriate time. Students can create remembrance projects individually or in groups. In each case, the project should have the same stages - selecting a topic, defining objectives, agreeing with students, developing a plan and a schedule, and implementing, presenting, and evaluating the project. ${ }^{67}$ Projects whose final product is, for example, a multimedia presentation, may be implemented in both primary and secondary schools. However, we should adapt the project methodologies to students' psychological and physical development, and to account for students with special educational needs. ${ }^{68}$

An educational project conducted at a place of remembrance is therefore a form of education oriented towards applying knowledge in practice and fostering the development of conceptual and teamwork skills. ${ }^{69}$ The project method allows students to interact with artefacts and documents, that is, to directly experience history-something which traditional classroom education cannot provide. A project conducted on the premises of a museum of

\footnotetext{
${ }^{65}$ Compare: BRUDNIK, Edyta, MOSZYŃSKA, Anna, and OWCZARSKA, Beata. Ja i mój uczeń pracujemy aktywnie. Przewodnik po metodach aktywizujacych. Kielce: Wydawnictwo Jedność, 2000.

${ }^{66}$ There are numerous studies devoted to the Project method, such as: NEIRICH, Uwe. Erinneren heißt wachsam vleiben. Pädagoische Arbeit in uns NS-Gedaenkstätten. Mülheim an der Ruhr: AK Ruhr, 2000, pp. 42-77.; ZAJĄC, Bożena. Metoda projektów jako strategia postepowania dydaktycznego w liceum profilowanym. Lódź: Lódzkie Centrum Doskonalenia Nauczycieli i Kształcenia Praktycznego, 2002; GLOWACKI, Stanisław. Metoda projektów jako narz̨dzie integracji. Kielce: Wojewódzki Ośrodek Metodyczny, 1999; KRÓLIKOWSKI, Jacek. Projekt edukacyjny—materiaty dla zespołów międryprzedmiotowych. Warszawa: Centralny Ośrodek Doskonalenia Nauczycieli, 2000; MIKINA, Agnieszka. Metoda projektów w kreowaniu przedsiębiorczych postaw uczniów. Warszawa: Wydawnictwa Szkolne i Pedagogiczne, 1997.

${ }^{67}$ JADCZAK, Maria. Metoda projektów w nauczaniu historii i wiedzy o społeczeństwie. In: ROSZAK, Stanisław, STRZELECKA, Roszak Małgorzata, and WIECZOREK, Agnieszka (eds). Miejsca pamięci w edukacji historycznej, vol. VI. Toruń: Stowarzyszenie Oświatowców Polskich, 2009, pp. 2522-2555.

${ }^{68}$ Rozporzadzenie z dnia 9 sierpnia 2017 roku w sprawie zasad udzielania i organizacji pomocy psychologiczno -pedagogicznej w publicznych przedszkolach, szkołach i placówkach (Dz. U. 25 August 2017 pos. 1591).

${ }^{69}$ KRANZ, Edukacja w miejscach pamieci..., p. 21.
} 
martyrdom requires a lot of effort on the part of museum educators, teachers, and students; at the same time, it can also be a source of satisfaction for all participants. ${ }^{70}$ Interdisciplinary projects based on the cross-curricular teaching model, showing various levels and perspectives of the relationship between the past and the present, are extremely valuable in the process of developing key competences. As Volkhard Knigge writes,

If we want to strengthen civic consciousness through historical exhibitions, we must leave space for viewers to reflect, to ask their own questions, and to build analogies between history and the present by referring to their own experience. ${ }^{71}$

The educational activity of museums is considered as non-formal education, that is, a voluntary form of learning that occurs outside the formal education system. This type of education is seen as supporting the development of competences to which sufficiently large amounts of time cannot be devoted in the education system. Non-formal education is characterised by a free choice of place and time to study, non-compulsory teaching content, the use of various teaching and learning methods, a multi-directional process of interactions and relations between people participating in this form of education, and the lack of formal recognition of the acquired knowledge and competences. ${ }^{72}$ Non-formal education is also defined as a lifelong process, including not only expanding knowledge and skills, but also shaping attitudes and values using innovative and active teaching methods. Martyrdom museums, despite the fact that they conduct informal education, more and more often become institutions open to the needs of the education system. This statement points to the need to constantly create new forms of cooperation between schools and museums of martyrdom. Among the forms of informal education provided by martyrdom museums in Poland, the dominant ones are those that allow direct contact with the historical heritage, that is: tours, lessons at the museum, exhibitions, workshops (including therapeutic workshops for people with disabilities and those who are socially excluded), and educational projects.

However, this cooperation requires the involvement of both institutions-museums of martyrdom as well as schools, teachers, and educators. Cooperative activities should be conducted at various levels, ranging from developing curricula and lesson plans to academic competitions and educational projects. According to those who study historical education:

A well-prepared lesson in a museum, developed in accordance with the curriculum and in cooperation with a history teacher, promotes a better assimilation of knowledge, teaches observation and comparison, and finally allows for the concretisation of ideas that are the basis for the formation of historical concepts. ${ }^{73}$

\footnotetext{
${ }^{70}$ NEIRICH, Uwe. Erinnernheißt wachsambleiben. Pädagogische Arbeit in und mit NS-Gedenkstätten. Mülheim; Verlag an der Ruhr, 2000.

${ }^{71}$ WÓYCICKA, Zofia. Zofia Wóycicka spoke to Professor Volkhard Knigge on the occasion of the planned opening of an exhibition devoted to forced labourers in Warsaw in January 2013. In: Zagłada Żydów. Studia I Materialy, 8, 201, p. 492; BANACH, Krzysztof. Exhibiting Violence or Teaching Values? Historical Exhibitions at a Modern Museum of Martyrdom. In: Przeglad Historyczny, 107, 1, 2016, p. 94.

${ }^{72}$ KURZEPPA, Jacek. O potrzebie komplementarności w edukacji formalnej i nieformalnej: aplikacje teoretyczno-praktyczne. In: KACZANOWSKA, Jagna (ed). Doświadczać uczenia. Materiały konferencyjne. Warszawa: Fundacja Rozwoju Systemu Edukacji, pp. 45-52.

${ }^{73}$ CHORAZZY, Ewa, KONIECZNA-ŚLIWIŃSKA, Danuta, and ROSZAK, Stanisław. Edukacja historycznna w sq̨ole-teoria i praktyka. Warszawa: Wydawnictwo Naukowe PWN, 2008, p. 258.
} 
Museums of martyrdom "combine the power of the real thing and the real place", ${ }^{74}$ so that by visiting these places, students have the opportunity to interact with both history and the memory of the place. In practice, this learning process is based on the students' activity, on creating situations that foster an independent understanding of history, the "discovery" of historical truth, and the drawing of appropriate conclusions.

Informal education provided by martyrdom museums is an activity aimed at the future. This education is not about direct teaching, but first and foremost about learning. In practice, this means that more attention in the education process is paid to the activity of participants in pedagogical projects carried out by martyrdom museums, creating opportunities for independent research, discovering historical truth and thus reaching conclusions, rather than transmitting only historical facts. The theorists of the pedagogy of remembrance also emphasise other attributes of martyrdom museums, such as interdisciplinarity and empiricality. ${ }^{75}$ Martyrdom museums are carriers of memory and are based on universal values; therefore they are a good starting point for a lively dialogue and are places that encourage people to draw the right conclusions. The pedagogy of remembrance is therefore an attempt to activate historical memory of totalitarian crimes and at the same time to stimulate actions for the future in the spirit of emancipation and empathy. As a form of extracurricular historical and social education, it is an important element in teaching history and developing the competences of the future.

The Polish educationalist Jerzy Maternicki recognised that "inquiry into historical truth by students is, of course, possible only if they are properly prepared for it". ${ }^{76}$ A visit to a museum of martyrdom is intended to consolidate, systematise, and deepen knowledge previously acquired during history lessons in the classroom, as well as to acquire new knowledge through direct contact with the place of remembrance. It is noteworthy that after visiting such a memorial, students often emphasise its emotional impact. ${ }^{77}$ Respecting the principle of subjectivity at places of remembrance, that is, the right to ask questions, to obtain reliable answers, to decide collectively, to cooperate, to express one's opinion, and to criticise, plays an important role in the process of shaping the competences of the future. ${ }^{78}$ These skills should also be seen as competences of the future.

In conclusion, it should be noted that museums of martyrdom, which are places of atrocity, barbarism, suffering, and mass extermination, also have an educational function focused on cognitive processes, and are a support for schools in developing key competences. ${ }^{79}$ These museums not only shape historical awareness, but also foster the development of social competences included in the competences of the future, such as tolerance, respect for human rights, negotiation, conflict resolution, teamwork, empathy, courage, ethics, and non-chauvinist attitudes. Thus, the pedagogy of remembrance is a form of education with great didactic

\footnotetext{
${ }^{74}$ ZIĘBIŃSKA-WITEK, Anna. Estetyki reprezentacji śmierci w ekspozycjach historycznych. In: FABISZAK, Małgorzata and OWSINSKI, Marcin (eds). Obóz-muz̨eum Trauma we wspótczesnym wystawiennictwie. Kraków: Towarzystwo Autorów i Wydawców Prac Naukowych, 2013, p. 32.

${ }^{75}$ GRUNEWALD, Dawid. The Best of Both Worlds: A Critical Pedagogy of Place. In: Educational Researcher, 4, 2003 , p. 7.

${ }^{76}$ MATERNICKI, Jerzy. Prawda historyczna jako zadanie dydaktyczne. In: RULKA Janusz (ed). Wartości w edukacji historycznej. Bydgoszcz: Wyższa Szkoła Pedagogiczna, 1999, pp. 29-42.

${ }_{77}$ STEC, Katarzyna. Symbolika i znaczenie miejsc pamięci utworzonych na terenach byłych obozów koncentracyjnych i zagłady z perspektywy współczesnego młodego człowieka. In: KUCIA, Marek. (ed). Antysemityzm, Holocaust, Auschwitz, w badaniach społecznych. Kraków: Wydawnictwo Uniwersytetu Jagiellońskiego, 2011, pp. 37-54.

${ }^{78}$ KRANZ, Edukacja w miejscach pamięci..., p. 20.

${ }^{79}$ SZPOCIŃSKI, Andrzej. Wyłamanie się nowego ładu edukacyjnego we współczesnej Polsce. In: Kultura Wspótczesna, 3, 2003, pp. 51-57.
} 
and pedagogical potential. The authenticity of the crime scene itself evokes emotions, fosters experiential learning, and makes one reflect on the past and draw inferences, and as a result supports the formation of appropriate attitudes and key competences. The pedagogy of remembrance is a

reflection on the experience of others, which leads to self-reflection; it is the development of historical thinking, which helps us to better understand the present, as well as an attempt to shape non-conformist attitudes and behaviours, based on a sense of empathy and responsibility for the fate of others. ${ }^{80}$

Museums of martyrdom can therefore be seen as a form of extracurricular historical education which, by familiarising pupils with the tragic events of the Second World War, supports the process of shaping the key competences necessary for the proper functioning of the individual in the future.

\section{References}

ADAMSKA, Jolanta (1998). Pamięć i miejsca pamięci w Polsce po II wojnie światowej. In: Przesz̧łość I Pamię́c, 1, pp. 4-11. ISSN 14283662.

ADORNO, Theodor W. (1970). Erziehung zur Mündigkeit. Frankfurt: Suhrkamp; 1st. Ed. ISBN 9783518365113.

AUGE, Marc (1995). Non-Places: Introduction to an Anthropology of Supermodernity. New YorkLondon: Verso. ISBN 1-8-5984-956-3.

BAKER, Alan R. H. (2003). Geography and History: Bridging the Divide. Cambridge: Cambridge University Press. ISBN 0521246830.

BANACH, Krzysztof (2016). Exhibiting Violence or Teaching Values? Historical Exhibitions at a Modern Museum of Martyrdom. In: Preglad Historyczny, 107,1, pp. 77-100. ISSN 00332186.

BANACH, Krzysztof (2017). Muzeum martyrologiczne jako muzeum konstruktywistyczne. In: KRANZ Tomasz (ed.), Muzea w poobozowych miejscach pamięci. To żsamość, zৃnaczenia, funk.je. Lublin: Państwowe Muzeum na Majdanku, pp. 691-05. ISBN 9788362816361.

BORGENSZTAJN, Joanna, KARCZEWSKA-GZIK, Agnieszka, MILEWSKA, Marta, WITKOWSKA, Elżbieta, and MALINOWSKI, Michał (2018). Wytyczne wraz z aneksem do tworzenia programów nauczania i scenariuszy zajéc, accessed 14 December 2020, https://www. ore.edu.pl/wpcontent/uploads/2018/08/wytyczne_wraz_z_aneksem_do_tworzenia_ programow_nauczania-1.pdf.

BRINKMANN, Annette (ed.) (2000). Learning from History. The Nazi Era and the Holocaust in German Education. Bonn: American Association of Teachers of German. ISBN-3-93039523-1.

BRIX, Emil, BRUCKMüLLER Ernst, and STEKL, Hannes (eds.) (2004-2005). Memoria Austriae, vol. 1-3. Wien-München: Verlag für Geschichte und Politik. ISBN 3486568388.

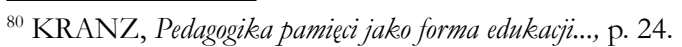


BRUDNIK, Edyta, MOSZYŃSKA, Anna, and OWCZARSKA, Beata (2000). Ja i mój uczeń pracujemy aktywnie. Præewodnik po metodach aktywizujacych. Kielce: Wydawnictwo Jedność, ISBN 9788376604435.

CASEY, Edward (1997). The Face of Place. A Philosophical History. Berkeley: University of California Press. ISBN 052092200X, 9780520922006.

CHAŁAS, Krystyna (2018). Przyszłość należy do świadomych i aktywnych obywateli. Jakie kompetencje są im niezbędne? Jak skutecznie je kształtować? (Perspektywa aksjologiczna). In: KWIATKOWSKI, Stanisław (ed.), Kompetencje praysszłości. Warszawa: Fundacja Rozwoju Systemu Edukacji, pp. 30-66. ISBN 978365591524.

CHORAZŻY, Ewa, KONIECZNA-ŚLIWIŃSKA, Danuta, and ROSZAK, Stanisław (2008). Edukacja historyczna w szkole-teoria i praktyka. Warszawa: Wydawnictwo Naukowe PWN. ISBN 9878301154431.

COUNCIL RECOMMENDATIONOF 22 MAY 2018 on key competences for lifelonglearning. Official Journal of the European Union C 189, p. 7, accessed on 4 February 2021, https: / eurlex.europa.eu/legal content/EN/TXT/HTML/?uri=OJ:C:2018:189:FULL\&from=EN.

CZERNER, Anna and NIEROBA, Elżbieta (2017). Na styku historii i codzienności. Spoteczność lokalna wobec miejsc pamięci. Opole: Centralne Muzeum Jeńców Wojennych. ISBN 9788361801306.

DEWEY, John (1997). Experience and Education. New York: Simon \& Scuster. ISBN 0684838281.

EHMANN, Annegret, (ed.) (1995). Praxis der Gedenkstättenpädagogik. Erfahrungen und Perspektiven. Opladen: Leske und Budrich. ISBN 3810013935.

FAULKNER, William (1951). Requiem for a Nun. New York: Random House. ISBN 009958591X.

FOLGA-JANUSZEWSKA, Dorota (2008). Muzeum: definicja i pojęcie. Czym jest muzeum dzisiaj? In: Muzeologia, 49, pp. 200-204. ISSN 0464-1086.

FOUCAULT, Michael (1975). Discipline and Punish. The Birth of the Prison. New York: Random House. ISBN 0679752552.

FRANCOIS, Etienne and SCHULZE, Hagen (eds.) (2001-2003). Deutsche Erinnerungsorte, vol. 1-3. München: Verlag C.H. Beck. ISBN 3406472249.

GLOWACKI, Stanisław (1999). Metoda projektów jako narz̨edzie integracij. Kielce: Wojewódzki Ośrodek Metodyczny. ISBN 8387260460.

GOLKA, Marian (2008). Pamięć spoteczna i jej implanty. Warszawa: Scholar. ISBN 9788373834002. HARTMUT, John and DAUSCHEK, Anja (eds.) (2008). Museen neu denken. Perspektiven der Kulturvermittlung und Zielgruppenarbeit. Bielefeld: transcript Verlag, Landschaftsverband Rheinland, Rheinisches Archiv-und Museumsamt. ISBN 978-3-89942-802-5.

HAUG, Verena (2015). Am ,autentischen” Ort. Paradoxien der Gedenkstätten pedagogik. Berlin: Metropol Verlag. ISBN 9789186261689.

HEIN, G. (1998). Learning in the Museum. London: Routledge. ISBN 9780415097765.

JADCZAK, Maria (2009). Metoda projektów w nauczaniu historii i wiedzy o społeczeństwie. In: ROSZAK, Stanisław, STRZELECKA, and Małgorzata, WIECZOREK, Agnieszka (eds.), Miejsca pamięci w edukacji historycznej. Toruń: Stowarzyszenie Oświatowców Polskich, t. VI, pp. 252-255. ISBN 9788373521896.

KAHLS, Heike (1996). Erinnern lernen? Pädagogische Arbeit in Gedenkstätten. Münster: Agenda Päda-gogik. ISBN 3-929440-80-6.

KLIMOWICZ, Anna (ed.) (2004). Edukacja mięzyykulturowa. Poradnik dla nauczyciela. Warszawa: Ośrodek Rozwoju Edukacji. ISBN 8387958492. 
KMIEC, Sonja, MAJERUS, Bonoit, MARGUE, Michel, and PEPORTE, Pit (2007). Lieux de mémoire au Luxembourg. Usages du passé et construction nationale. Erinnerungsorte in Luxemburg. Umgang mit der Vergangenheit und Konstruktion der Nation. Luxembourg: Éditions Saint-Paul. ISBN 9782879637051.

KRANZ, Tomasz (2005). Pedagogika miejsc pamięci. In: PILCH, Tadeusz (ed.), Encyklopedia pedagogiczna XXI wieku. Warszawa: Wydawnictwo Akademickie Żak, 2005, vol. 4, pp. 170 173. ISBN 8389501414.

KRANZ, Tomasz (2012). Pedagogika pamięci jako forma edukacji muzealnej. In: KRANZ, Tomasz (ed.), Wi izyty edukacyjne w Państwonym Muzeum na Majdanku. Poradnik dla nauczycieli. Lublin: Muzeum Państwowe na Majdanku, pp. 11-26. ISBN 9788-62816040.

KRANZ, Tomasz (2003). Uwagi na temat rozwoju działalności pedagogicznej muzeów upamiętnienia w Polsce i Niemczech. In: Zeszyty Majdanka, 22, pp. 401-415. ISSN 05147409. KRANZ, Tomasz (2004). Pedagogika miejsc pamięci. In: Obyczaje, 16, pp. 5-8. ISSN15068331. KRANZ, Tomasz (2009). Edukacja historyczna w miejscach pamięci. Zarys problematyki. Lublin: Stowarzyszenie „Dialog i Współpraca”. ISBN 839251873X.

KRANZ, Tomasz (2010). Pedagogika pamięci. In: Nigdy wiecej, 18. ISSN14280884.

KRANZ, Tomasz (2015). Einleitung. In: KRANZ, Tomasz (ed.), Zur Pädagogik der Erinnerung. Bedingungen, Ziele und MethodenhistorischerBildung in Gedenkstätten. Lublin: Państwowe Muzeumna Majdanku, pp.7-9. ISBN 9788362816262.

KRIES, Georg (2010). Schweizer Erinnerungsorte. Aus dem Speicher der Swissness. Zürich: Verlag Neue Zürcher Zeitung. ISBN: 978-3- 03823-591-0.

KROH, Jens (2006). Transnatiionale Erinnerung. Der Holocaust im Fokus geschichtspolitischer Iniciativen. Frankfurt-New York: Amazon.de: Bücher. ISBN 3593385988.

KRÓLIKOWSKI, Jacek (2000). Projekt edukacyjny-materiaty dla zespotón międzyprzedmiotonych. Warszawa: Centralny Ośrodek Doskonalenia Nauczycieli. ISBN83-879558158.

KUPISIEWICZ, Czesław (2000). Dydaktyka ogólna. Warszawa: Graf-Punkt. ISBN 838798857X. KURZĘPA, Jacek (2003). O potrzebie komplementarności w edukacji formalnej i nieformalnej: aplikacje teoretyczno-praktyczne. In: KACZANOWSKA, Jagna (ed.), Doświadczać uczenia. Materialy konferencyjne. Warszawa: Fundacja Rozwoju Systemu Edukacji, pp. 45-52.

KWIATKOWSKI, Stanisław (2018). Kompetencje przyszłości. In: KWIATKOWSKI, Stanisław (ed.), Kompetencje prayszłości. Warszawa: Fundacja Rozwoju Systemu Edukacji, pp.14-29. ISBN 978365591524.

MAJEWSKI, Piotr. Mureum jako instytucja komunikacji spotecænej, Narodowy Instytut Muzealnictwa i Ochrony Zabytków, accessed 8 December 2020, https://docplayer.pl/7438611-Muzeum-jakoinstytucja-komunikacji-spolecznej-1.html.

MALPAS, Jodi Ellen (1999). Place and Experience: A Philosophical Topography. Cambridge: Cambridge University Press. ISBN 0512642175.

MATERNICKI, Jerzy (1999). Prawda historyczna jako zadanie dydaktyczne. In: RULKA Janusz (ed.), Wartości w edukacii historycznej. Bydgoszcz: Wyższa Szkoła Pedagogiczna, pp. 29-42. ISBN 8370962777.

MATHIJSEN, Marita (2012). Plaatsen van herinnering. Nederland in de negentiende eeuw. Amsterdam: Bert Bakker. ISBN 9789035129504.

MAYER, Jack and SALOVEY, Peter (1999). Czym jest inteligencja emocjonalna? In: SALOVEY, Peter and SLUYTER, Dawid (eds.), Rozwój emocjonalny a inteligencja emocjonalna. Problemy edukacyjne. Poznań: Dom Wydawniczy Rebis, pp. 23-69. ISBN 837120695X. 
MAZUR-RAFAŁ, Monika and SZAROTA, Magdalena (2013). Edukacja na rzecz praw człowieka. Zarys metodologiczny. In: MILCZARSKI, Radosław, MAZUR-RAFAt, Monika, SZAROTA, Magdalena, LIPKA, Monika, and CZAJKA, Katarzyna (eds.), Historia a prawa człowieka. Podrecznik. Warszawa: Wydawnictwo Ośrodek Karta, pp. 315-2. ISBN 9788361283782.

MIKINA, Agnieszka (1997). Metoda projektów w kreowanin przedsiębiorczych postaw uczniów. Warszawa: Wydawnictwa Szkolne i Pedagogiczne. ISBN 8302065714.

MILEWSKA, Marta (2017). Prawa człowieka w edukacji historycznej w gimnazjum. In: JASKIERNIA, Jerzy and SPRYSZAK, Kamil (eds.). Ochrona praw człowieka w Polsce. Aksjologia — instytucje — nowe wyzwania — praketyka. Torun: Wydawnictwo Adam Marszałek, vol. IV, pp. 263-6. ISBN 9788380196292.

NAPIONEK, Olga (2013). Kompetencje społeczne i obywatelskie_czym są i w jaki sposób można je rozwijać dzięki projektom edukacyjnym? In: TOEWIŃSKA-KRÓLIKOWSKA, Elżbieta (ed.), Džieci obywatele. Warszawa: Fundacja Inicjatyw Oświatowych, pp. 182-2. ISBN 9788391518465.

NEIRICH, Uwe (2000). Erinnern heißt wachsam bleiben. Pädagogische Arbeit in und mit NSgedenkstä̈tten. Mülheim: Verlag an der Ruhr. ISBN 9783000299810.

NIETZSCHE, Friedrich (1980). On the Advantage and Disadvantage of History for Life. Indianapolis: Hackett. ISBN 0915144948.

NORA, Pierre (1984-1992). Les lieux de mémoire. Paris: Gallimard, pp. 1-7. ISBN 23-05-1997.

NORA, Pierre (2006). Rethinking France. Les Lieux de memoire, Volume 2: Space. Chicago: University of Chicago Press. ISBN 0226591336.

NORA, Pierre (1989). Between Memory and History. Les Lieux de mémoire. In: Representation, 26, pp. 72-4. ISBN 0734-6018.

OKOŃ, Wincenty (2001). Nowy stownik pedagogiczny. Warszawa: Wydawnictwo Akademickie Żak. ISBN 8388149415.

PANIMASZ, Katarzyna and LEWANDOWSKI, Grzegorz (eds.) (2012). Historia i społeczeństwo. Planowanie—realizacja—ewaluacja. Warszawa: Ośrodek Rozwoju Edukacji.

POMIAN, Krzysztof (2009). Muzeum: kryteria sukcesu. In: Murealnictwo, 50, pp. 576-4. ISSN 0464-1086.

PRAK, Maarten (2006). Plaatsen van herinnering. Nederland in de zeventiende en achttiende eeuw. Amsterdam: Bert Bakker. ISBN 9789035129900.

RATHENOW, Hanns-Fred (1999). Gedankstättenpädagogik. In: RICHTER, Dagmar and WEIßENO, Georg (eds.) Lexikon der politischen Bildung, BD. 3 (Didaktik Und Schule). Schwalbad: Wochenschau Verlag, pp. 798-2. ISBN 3879200432.

RICOEUR, Paul (2004). Memory, History, Forgetting. Chicago: University of Chicago Press. ISBN 0-226-71342-3.

Rozporzqdzenie z dnia 9 sierpnia 2017 roku w sprawie zasad udzielania i organizacji pomocy psychologiczno -pedagogicznej w publicznych przedszkolach, szkotach i placówkach (Dz. U. 25 August 2017 pos. 1591).

SCHEURICH, Imke (2010). NS-Gedenkstätten als Orte kritischer historisch-politischer Bildung. In: THIMM, Barbara, KÖßLER, Gottfried, and ULRICH. Susanne (eds.), Verunsichernde Orte, Selbstverständnis und Weiterbildung in der Gedenkstättenpädagogik. Frankfurt am Main: Brandes + Apsel Verlag Gm, pp. 38-44. ISBN 103860996304. 
SIKORSKA-MICHALAK, Anna and WOJNIŁKO, Olga (eds.) (1996). Stownik wspótczesnego jezyka polskiego. Warszawa: Wydawnictwo Wilga. ISBN 8371560680.

SKRIVER, Ansgar (1962). Aktion Suehnezeichen. Bruecken ueber Blut und Asche. Stuttgart: Walter de Gruyter. ISBN 978-3-11-066108-8.

SMITH, Anthony (2000). Myths and Memories of the Nation. Oxford-New York: Oxford University Press. ISBN 0198296843.

STAWOWY, Ewa (2009). Edukacja o prawach czlowieka. Strategia dla organizacji pozarzqdowych $i$ placówek kulturalno-oswiatowych. In: KOBA, Laura and WACKAWCZYK, Wiesław (eds.). Prawa człowieka. Wybrane zagadnienia i problemy. Warszawa: Oficyna a Wolters Kluwer business, pp. 5595-5592. ISBN 9788376013343.

STEC, Katarzyna (2011). Symbolika i znaczenie miejsc pamięci utworzonych na terenach byłych obozów koncentracyjnych i zagłady z perspektywy współczesnego młodego człowieka. In: KUCIA, Marek (ed.). Antysemityzm, Holocaust, Auschwitz w badaniach społecznych. Kraków: Wydawnictwo Uniwersytetu Jagiellońskiego, pp. 37-42. ISBN 9788323332275.

SZPOCIŃSKI, Andrzej (2003). Wyłamanie się nowego ładu edukacyjnego we współczesnej Polsce. In: Kultura Wspótczesna, 3, pp. 51-7. ISSN 12304808.

TOTT, Samuel. (ed.) (2001). Teaching Holocaust Literature. Boston: Macmillan. ISBN 0230019366.

VON HENTIG, Hartmut. (1993). Die Schule nue denken. München: Beltz; Lizenzausgabe Edition. ISBN 3407221193.

WEBER, Norbert H. and RARHENOW, Hanns-Fred (1996). Education at the memorials: an asesament. In: Kwartalnik Pedgogiczny, Wydział Pedagogiczny Uniwersytetu Warszawskiego, 2, pp. 376-379 ISSN: 00235938.

WEBNER, Norbert and RATHENOW, Hanns-Freud (1996). Pedagogika miejsc pamięcipróba bilansu. Translated by SZYMANSKI, Mirosław and LEWANDOWSKA, Izabela. In: Kwartalnik Pedagogiczny, 2, pp. 33-36. ISSN 9788362816392.

WYSOK, Wiesław (2013). Edukacja w muzeach upamiętnienia in situ—postulaty, możliwości i granice oddziaływania dydaktycznego. In: WYSOK Wiesław and STĘPNIAK Andrzej. (eds.), Edukacja muzealna w Polsce. Aspekty, konteksty, ujęcia. Lublin: Muzeum Państwowe na Majdanku, pp. 396-398. ISBN 9783628161251.

WYSOK, Wiesław (2014). Wokół problematyki uwarunkowań i efektów edukacji w muzeach upamiętnienia. In: Zeszyty Majdanka, 26, pp. 3113-3140. ISSN 05147409.

YVONNE, Leonard (ed.) (2012). Kindermuseen, Strategien und Methoden eines aktuellen Museumstyps. Bielefeld: Transcript Verlag. ISBN 3837620786.

ZACHARIAS, Wolfgang (1990). Zeitphänomen Musealisierung. Das Verschwinden der Gegenwart und die Konstruktion der Errinerung. Essen: Klartext. ISBN-13: 9783884746042.

ZAJĄC, Bożena (2002). Metoda projektów jako strategia postepowania dydaktycznego w liceum profilowanym. Lódź: Lódzkie Centrum Doskonalenia Nauczycieli i Kształcenia Praktycznego. ISBN 9788323228967.

ZIĘBIŃSKA-WITEK, Anna (2013). Estetyki reprezentacji śmierci w ekspozycjach historycznych. In: FABISZAK, Małgorzata and OWSIŃSKI, Marcin (eds.). Obóz-muzeum Trauma we wspótczesnym wystawiennictwie. Kraków: Towarzystwo Autorów i Wydawców Prac Naukowych Universitas, pp. 315-314. ISBN 9788324223619.

WÓYCICKA, Zofia (2013). Zofia Wóycicka spoke to Professor Volkhard Knigge on the occasion of the planned opening of an exhibition devoted to forced labourers in Warsaw in January 2013. In: Zagłada Żydów. Studia i Materiały, 8, p. 492. ISSN1895247X. 